\title{
RZECZNIK MAŁYCH I ŚREDNICH PRZEDSIĘBIORCÓW: OMBUDSMAN CZY ORGAN ADMINISTRACJI RZĄDOWEJ?
}

\section{GENEZA INSTYTUCJI RZECZNIKA MALYCH I ŚREDNICH PRZEDSIĘBIORCÓW}

Oryginalną koncepcją związaną z uchwaleniem pięciu ustaw określanych mianem „Konstytucji Biznesu”, wśród których najważniejszym aktem jest Prawo przedsiębiorców i które w założeniu ich twórców mają stanowić „największą reformę prawa gospodarczego po 1989 roku” oraz przynieść „pozytywny przełom $\mathrm{w}$ relacjach pomiędzy administracją publiczną a przedsiębiorcami”", było ustanowienie instytucjonalnych gwarancji wdrożenia zasad wyrażonych $\mathrm{w}$ tych przepisach. Twórcy reformy na etapie opracowania projektów poszczególnych aktów prawnych wskazali aż dwa organy, których utworzenie miało służyć zagwarantowaniu rzeczywistego stosowania zasad określonych w Prawie przedsiębiorców w relacjach pomiędzy przedsiębiorcami a organami władzy publicznej, ochronie praw przedsiębiorców, a także kształtowaniu i poprawie warunków podejmowania i wykonywania działalności gospodarczej. Tymi organami miały być Rzecznik Przedsiębiorców oraz Komisja Wspólna Rządu i Przedsiębiorców³ .

${ }^{1}$ W skład „Konstytucji Biznesu” wchodzą następujące ustawy uchwalone 6 marca 2018 r.: ustawa - Prawo przedsiębiorców (Dz. U. 2018, poz. 646; dalej jako: Pr.przeds.); ustawa o Centralnej Ewidencji i Informacji o Działalności Gospodarczej i Punkcie Informacji dla Przedsiębiorcy (Dz. U. 2018, poz. 647); ustawa o Rzeczniku Małych i Średnich Przedsiębiorców (Dz. U. 2018, poz. 648; dalej jako: ustawa o RMSP); ustawa o zasadach uczestnictwa przedsiębiorców zagranicznych i innych osób zagranicznych w obrocie gospodarczym na terytorium Rzeczypospolitej Polskiej (Dz. U. 2018, poz. 649) oraz ustawa - Przepisy wprowadzajace ustawę - Prawo przedsiębiorców oraz inne ustawy dotyczące działalności gospodarczej (Dz. U. 2018, poz. 650). Przepisy tych aktów prawnych (poza nielicznymi wyjątkami) weszły w życie 30 kwietnia 2018 r.

2 Zob. opracowanie Ministerstwa Rozwoju Konstytucja Biznesu przedstawione 18 listopada 2016 r., s. 3, <https://www.mf.gov.pl/documents/764034/5123672/Konstytucja_Biznesu_stan_na_ listopad_2016.pdf> [dostęp: 5.09.2018].

${ }^{3}$ Zob. art. 73 zawartego w opracowaniu Konstytucja Biznesu projektu ustawy Prawo przedsiębiorców, stanowiący, że „Komisja Wspólna Rządu i Przedsiębiorców stanowi forum wypracowywania wspólnego stanowiska Rządu i przedsiębiorców”, i art. 74 stanowiący, że „Rzecznik Przedsiębiorców stoi na straży praw przedsiębiorców określonych w Konstytucji Rzeczypospolitej Polskiej, niniejszej ustawie i innych przepisach prawa”. Szczegółowe zadania wymienionych organów zostały określone w przepisach projektu ustawy o Komisji Wspólnej Rządu i Przedsiębiorców oraz Rzeczniku Przedsiębiorców z 10 lutego 2017 r. (dalej jako: projekt ustawy o KWRiPoRP), 
Idea utworzenia organów powołanych do „wspierania i monitorowania właściwego wdrożenia w praktyce” przepisów Konstytucji Biznesu (jak napisano w uzasadnieniu projektu ustawy o KWRiPoRP) oraz ochrony praw przedsiębiorców nie ma swego odpowiednika we wcześniej obowiązujących ustawach dotyczacych zasad podejmowania, wykonywania i zakończenia działalności gospodarczej, w szczególności w przepisach ustawy z 19 listopada 1999 r. Prawo działalności gospodarczej ${ }^{4}$ oraz w przepisach ustawy z 2 lipca 2004 r. o swobodzie działalności gospodarczej ${ }^{5}$. Idea wyrażona w przepisach projektu ustawy o KWRiPoRP nie została jednak urzeczywistniona w takim kształcie, jak zakładano pierwotnie.

Po pierwsze, zrezygnowano z utworzenia Komisji Wspólnej Rządu i Przedsiębiorców (KWRiP). Pomysł utworzenia tego organu, który miał się składać z przedstawicieli rządu i przedsiębiorców (bez udziału innych środowisk), a którego zadaniem miało być rozpatrywanie spraw związanych z wykonywaniem działalności gospodarczej i polityką państwa wobec przedsiębiorców, w tym m.in. konsultowanie i opiniowanie projektów aktów normatywnych istotnych dla wykonywania działalności gospodarczej oraz wypracowywanie wspólnego stanowiska rządu i przedsiębiorców w tych sprawach (art. 1 ust. 2 oraz art. 2 projektu), był mocno krytykowany w toku prac legislacyjnych. Krytyka była wysuwana z różnych pozycji, oczywiście najsilniej ze strony tych organizacji uprawnionych do udziału w konsultacjach publicznych, z których zadaniami mogły pokrywać się zadania KWRiP. Do najważniejszych należał argument, że analogiczne funkcje realizuje już Rada Dialogu Społecznego (RDS), w której uczestniczą nie tylko organizacje reprezentujące przedsiębiorców, ale także organizacje reprezentujące pracowników, co powodowałoby erozję umocowanego konstytucyjnie trójstronnego dialogu społecznego. Zwracano uwagę także na to, że w składzie KWRiP nie uwzględniono udziału przedstawicieli wszystkich organizacji reprezentujących przedsiębiorców, a zwłaszcza organizacji branżowych i samorządów zawodowych ${ }^{6}$.

Po drugie, nie utworzono instytucji Rzecznika Przedsiębiorców. Także $\mathrm{w}$ odniesieniu do tej instytucji podnoszono argument, iż analogiczne funkcje realizują już inne organy i instytucje $\mathrm{e}^{7}$. W szczególności zwracano uwagę, że właściwą ochronę praw przedsiębiorców zapewnia stojący na straży przestrzegania praw obywateli Rzecznik Praw Obywatelskich (RPO) oraz że istnieje szereg innych instytucji państwowych, których zadaniem jest wspieranie prowadzenia działalności gospodarczej. Argumentowano, że utworzenie Rzecznika Przedsiębiorców spowoduje nierównowagę w sferze ochrony praw

a cele, którym służyć miało działanie tych organów, zostały przedstawione szerzej w uzasadnieniu wskazanego projektu (s. 1-3), <https://legislacja.rcl.gov.pl/projekt/12295219> [dostęp: 5.09.2018].

${ }^{4}$ Dz. U. 1999, Nr 101, poz. 1178 ze zm. (dalej jako: P.d.g.).

5 T.jedn.: Dz. U. 2017, poz. 2168 ze zm. (dalej jako: u.s.d.g.).

${ }^{6}$ Zob. Zatacznik do raportu z konsultacji projektu ustawy o Rzeczniku Przedsiębiorców (aktualny tytut - projekt ustawy o Rzeczniku Matych i Średnich Przedsiębiorców), pkt 4, 7 i 10; druk nr 2052, Sejm VIII kadencji.

${ }^{7}$ Zob. Raport z konsultacji projektu ustawy o Rzeczniku Matych i Średnich Przedsiębiorców, Warszawa, 8 września 2017 r., druk nr 2052, Sejm VIII kadencji, s. 1 i n. 
przedsiębiorców i praw pracowniczych, gdyż nie istnieje odrębna instytucja ochronna o tak szerokich kompetencjach jak przewidywane dla Rzecznika Przedsiębiorców, która stałaby na straży przestrzegania praw pracowniczych, w tym wolności zrzeszania się w związki zawodowe. Podnoszono wreszcie argument, że utworzenie omawianej instytucji może zniechęcać przedsiębiorców do wstępowania do organizacji pracodawców, których uprawnienia częściowo zostaną przejęte przez Rzecznika Przedsiębiorców. Zwracano ponadto uwagę, że odpowiednia przestrzeń, w której strony mogą wypracować rozwiązania na rzecz lepszego zagwarantowania przestrzegania praw przedsiębiorców, stanowi obecnie RDS.

W rezultacie zamiast ustawy o KWRiPoRP, bazując jednak w znacznym zakresie na przepisach zawartych w projekcie tej ustawy, uchwalono ustawę o RMSP. Przestawione okoliczności świadczą o tym, że utworzenie tego organu było działaniem niezamierzonym na etapie opracowywania zasadniczych zrębów „Konstytucji Biznesu” pod koniec 2016 r. (gdy opublikowano komunikat Ministerstwa Rozwoju pt. Konstytucja Biznesu) i na początku 2017 r. (gdy Rada Ministrów podjęła prace legislacyjne nad projektami ustaw wchodzacych w skład „Konstytucji Biznesu”). Ustanowienie instytucji, której zadania skupione są na ochronie praw tylko pewnej części podmiotów prowadzących działalność gospodarcza, a mianowicie mikro-, małych i średnich przedsiębiorców (MSP) ${ }^{8}$, jakkolwiek działalność tych właśnie podmiotów odgrywa szczególnie ważną rolę w gospodarce - było w istocie wypadkową wycofania się przez rząd z przyjętych pierwotnie, zupełnie innych założeń.

Analiza porównawcza projektowanych oraz uchwalonych przepisów prawnych pozwala jednak zauważyć wiele podobieństw pomiędzy przepisami jednego i drugiego aktu prawnego. Istnieją też wyraźne różnice pomiędzy Rzecznikiem Przedsiębiorców i Rzecznikiem MSP. Zakres zadań i kompetencji Rzecznika MSP jest wyraźnie szerszy w sferze udzielania ochrony prawnej, inaczej też określono charakter tego organu. Zrezygnowano z przepisu mówiącego, że jest on „centralnym organem administracji rządowej”, konsekwentnie natomiast posłużono się w jego nazwie określeniem „rzecznik”.

Wszystkie te okoliczności nieuchronnie wywołuja pytanie o to, z jakiego rodzaju organem mamy obecnie do czynienia. Czy jest to kolejny, wyspecjalizowany organ administracji czy może szczególny rodzaj ombudsmana, a więc rzecznika praw obywatelskich ${ }^{9}$, tym razem wyspecjalizowany w ochronie praw mikro-, małych i średnich przedsiębiorców? Próba odpowiedzi na to pytanie jest celem niniejszego artykułu. Dla realizacji tego celu niezbędne jest w pierwszej kolejności przyjrzenie się zadaniom i kompetencjom Rzecznika MSP.

\footnotetext{
${ }^{8}$ Pojęcia te zostały zdefiniowane w art. 7 ust. 1 pkt 1-3 Pr.przeds.

${ }^{9}$ Określenia „rzecznik praw obywatelskich” oraz „ombudsman” stosowane są w doktrynie prawa zamiennie; zob. T. Zieliński, Ombudsman - możliwości i granice działania, Warszawa 1994, s. 9 i n.
} 


\section{PROPOZYCJA KLASYFIKACJI ZADAŃ I KOMPETENCJI RZECZNIKA MSP}

Zadania Rzecznika MSP w sposób generalny określa art. 1 ust. 1 ustawy o RMSP. Zgodnie z tym przepisem, Rzecznik MSP stoi na straży praw MSP, w szczególności poszanowania zasady wolności działalności gospodarczej, pogłębiania zaufania przedsiębiorców do władzy publicznej, bezstronności i równego traktowania, zrównoważonego rozwoju oraz zasady uczciwej konkurencji i poszanowania dobrych obyczajów oraz słusznych interesów przedsiębiorców. Za pomocą analogicznych słów mówiących o „staniu na straży praw mikro-, małych i średnich przedsiębiorców" do zadań Rzecznika MSP odnosi się także art. 16 ust. 1 Pr.przeds. Warto dodać, że preambuła Pr.przeds. uznaje zagwarantowanie praw przedsiębiorców za jedną z najważniejszych przesłanek rozwoju działalności gospodarczej w warunkach wolnej konkurencji.

Sądząc po sposobie sformułowania przepisów określających szczegółowe zadania Rzecznika MSP, można uznać, że przepisy te są bardzo słabą strona ustawy o RMSP. Dotyczy to przede wszystkim art. 8, który zawiera listę zadań Rzecznika MSP. Jeśli bowiem najważniejszą funkcją wymienionego organu, w świetle art. 1 ww. ustawy, jest ochrona praw MSP, to także w art. 8 udzielanie tej ochrony powinno być umieszczone na pierwszym miejscu. Tymczasem przepis ten ochronę praw przedsiębiorców wymienia tylko w jednym punkcie, umieszczonym na ostatnim, piątym miejscu. Także sposób sformułowania analizowanego przepisu (,,podejmowanie innych działań, o których mowa w art. 9, o ile służą one ochronie praw przedsiębiorców”) pozostawia wiele do życzenia. Zadania służące ochronie praw przedsiębiorców zostały określone jako „inne działania”, co można odczytać jako nadanie im jakiejś „innej”, być może niższej rangi niż ranga pozostałych zadań wymienionych w art. 8. Zastanawia także, dlaczego użyto tu określenia „inne działania”, a nie po prostu „działania, o których mowa w art. 9", i dlaczego dodatkowo zastrzeżono, że działania te stanowią zadanie Rzecznika MSP tylko o tyle, „o ile służą one ochronie praw przedsiębiorców”.

Ustaleniu zadań Rzecznika MSP służy także analiza dalszych przepisów ustawy o RMSP. Zgodnie z wyjaśnieniami zawartymi w uzasadnieniu projektu tej ustawy (s. 6), w jej art. 9 określono instrumenty, które ustawa przyznaje Rzecznikowi MSP w celu wykonywania jego zadań. W mojej ocenie w art. 9 ustawy o RMSP wskazano nie tylko owe instrumenty prawne, ale także dalsze rodzaje zadań Rzecznika MSP, co w zestawieniu z treścią art. 8, a ponadto także z treścią art. 11 i 12 tej ustawy, pozwala na uporządkowanie zadań tego organu w pięciu następujących punktach:

1) podejmowanie interwencji w indywidualnych sprawach MSP,

2) podejmowanie działań na rzecz jednolitej wykładni przepisów prawnych dotyczących działalności gospodarczej,

3) podejmowanie działań na rzecz poprawy stanu prawa gospodarczego,

4) podejmowanie działań na rzecz poprawy praktyki funkcjonowania organów, organizacji oraz instytucji publicznych w sprawach MSP oraz 
5) propagowanie wiedzy na temat prawa gospodarczego oraz przedsiębiorczości.

O ile zadania wymienione przeze mnie w pkt 1 i 2 nie było do tej pory uregulowane w przepisach prawa gospodarczego, o tyle zadania ujęte w pkt 3-5 można odnaleźć w przepisach takich aktów prawnych, jak P.d.g. czy u.s.d.g., gdzie zadania te były określane mianem „wspierania działalności gospodarczej”, w tym „tworzenia korzystnych warunków dla funkcjonowania i rozwoju małych i średnich przedsiębiorców"10. Różnicę pomiędzy zadaniami wymienionymi w pkt 1 i 2 a zadaniami w sferze „wspierania działalności gospodarczej” stanowi także to, że obecnie jedynym wyspecjalizowanym organem właściwym w pierwszej z wyróżnionych sfer jest Rzecznik MSP, w drugiej natomiast właściwość posiadają także inne organy i instytucje. Należy do nich m.in. Pełnomocnik Rządu ds. Małych i Średnich Przedsiębiorstw powołany w 2017 r. w randze sekretarza stanu i działajacy w strukturach Ministerstwa Inwestycji i Rozwoju ${ }^{11}$ (wcześniej Ministerstwa Rozwoju) oraz Centrum Rozwoju MSP działające przy Polskiej Agencji Rozwoju Przedsiębiorczości. Na szczeblu unijnym istnieje Pełnomocnik ds. Małych i Średnich Przedsiębiorstw (Envoy for Small and Medium-Sized Enterprises), który działa jako przedstawiciel Komisji Europejskiej, prowadząc z jednej strony współpracę ze środowiskami małych i średnich przedsiębiorców i reprezentując ich interesy w procesie tworzenia prawa unijnego, z drugiej zaś - współdziałając z wyznaczonymi przez państwa członkowskie organami krajowymi (najczęściej w randze ministra), tworząc wraz z nimi Sieć Pełnomocników ds. Małych i Średnich Przedsiębiorstw (SME Envoys Network) ${ }^{12}$.

Ad 1. Dostrzegajac w Rzeczniku MSP organ ochrony prawnej, za niezwykle istotne zadanie należy uznać podejmowanie interwencji w indywidualnych sprawach przedsiębiorców. Rzecznik MSP posiada w tym zakresie szerokie kompetencje. Może zwrócić się o wszczęcie postępowania administracyjnego, wnosić skargi i skargi kasacyjne do sądu administracyjnego, a także uczestniczyć w tych postępowaniach na prawach przysługujących prokuratorowi, wnosić skargę nadzwyczajną na podstawie art. $89 \S 2$ ustawy o Sądzie Najwyższym ${ }^{13}$ lub żądać wszczęcia przez uprawnionego oskarżyciela postępowania przygotowawczego w sprawach o przestępstwa wszczynane

10 Szerzej na temat tych zadań zob. T. Rabska, Zadania administracji publicznej $w$ dziatalności gospodarczej (problem zakresu obowiazywania prawa działalności gospodarczej), „Ruch Prawniczy, Ekonomiczny i Socjologiczny" [RPEiS] 64, 2002, z. 2, s. 137 i n.; B. Popowska, Wspieranie matych $i$ średnich przedsiębiorców - charakterystyka przepisów prawa działalności gospodarczej $i$ ich realizacja, RPEiS 64, 2002, z. 2, s. 123 i n.; K. Kokocińska, Prawne aspekty wspierania rozwoju przedsiębiorczości - ustawa o swobodzie działalności gospodarczej oraz ustawy ustrojowo - kompetencyjne, RPEiS 67, 2005, z. 4, w szczególności s. 37 i n.

11 Zob. § 2 rozporządzenia Rady Ministrów z 17 października 2017 r. w sprawie ustanowienia Pełnomocnika Rządu do spraw Małych i Średnich Przedsiębiorstw (Dz. U. 2017, poz. 1929), wydane na podstawie art. 10 ust. 1 i 4 ustawy z 8 sierpnia 1996 r. o Radzie Ministrów (t.jedn.: Dz. U. 2012, poz. 392 oraz 2015, poz. 1064).

12 Zob. <https://eur-lex.europa.eu/legal-content/PL/TXT/?uri=LEGISSUM\%3An26035> [dostęp: 5.09.2018].

${ }^{13}$ Ustawa z 8 grudnia 2017 r. o Sądzie Najwyższym (t.jedn.: Dz. U. 2018, poz. 5 ze zm.). 
z urzędu (art. 9 ust. 1 pkt 6, 8 i 9 ustawy o RMSP). Udziela ponadto pomocy $\mathrm{w}$ organizacji mediacji między przedsiębiorcami a organami administracji publicznej (art. 8 pkt 2 ustawy o RMSP). Ustawa nie precyzuje form tej pomocy, zależnych od potrzeb i dostępnych środków, pozostawiając to uznaniu Rzecznika MSP. Przepisy ustawy o RMSP nie przewidują natomiast kompetencji tego organu do wstrzymania kontroli przedsiębiorcy w przypadku powzięcia uzasadnionego podejrzenia o naruszeniu przepisów prawa w toku jej przeprowadzania, co przewidywał projekt ustawy o KWRiPoRP. Pod wpływem uwag zgłoszonych w toku uzgodnień i konsultacji ww. projektu zrezygnowano $\mathrm{z}$ tego uprawnienia ${ }^{14}$.

Ad 2. W zakresie podejmowania działań na rzecz jednolitej wykładni przepisów prawnych dotyczących działalności gospodarczej Rzecznik MSP może występować do właściwych organów z wnioskiem o wydanie objaśnień prawnych, o których mowa w art. 33 Pr.przeds., jeśli przepisy będące przedmiotem wniosku budzą wątpliwości w praktyce lub ich stosowanie wywołało rozbieżności w rozstrzygnięciach wydawanych przez właściwy organ administracji publicznej ${ }^{15}$. Może także występować do SN z wnioskiem o rozstrzygnięcie zagadnienia prawnego w składzie 7 sędziów lub innym odpowiednim składzie oraz występować do NSA z wnioskiem o podjęcie uchwały mającej na celu wyjaśnienie przepisów prawnych, których stosowanie wywołało rozbieżności w orzecznictwie sądów administracyjnych (art. 9 ust. 1 pkt 2, 5 i 7 ustawy o RMSP). Dla ścisłości należy dodać, że sposób sformułowania przepisów Pr.przeds. dotyczących instytucji objaśnień prawnych (jak również dotyczących oceny funkcjonowania aktu normatywnego, o czym mowa w art. 69 ust. 1 Pr.przeds.) nie pozwala uznać, że owe objaśnienia i oceny mają dotyczyć wyłącznie spraw MSP. Tym samym działania Rzecznika MSP mogą niekiedy przynosić rezultaty odnoszące się do ogółu przedsiębiorców.

Ad 3. W zakresie trzeciego z wyróżnionych zadań, czyli podejmowania działań na rzecz poprawy stanu prawa gospodarczego, Rzecznik MSP ma obowiąek opiniowania projektów aktów normatywnych dotyczących interesów przedsiębiorców oraz zasad podejmowania, wykonywania lub zakończenia działalności gospodarczej na terytorium Rzeczypospolitej Polskiej (art. 8 pkt 1 ustawy o RMSP). Może także występować do właściwych organów z wnioskami o podjęcie inicjatywy ustawodawczej albo wydanie lub zmianę innych aktów normatywnych w sprawach dotyczących działalności gospodarczej oraz występować do właściwego ministra lub organu upoważnionego ustawowo do opracowywania i wnoszenia do rozpatrzenia przez Radę Ministrów projektów aktów normatywnych z wnioskiem o przygotowanie w trybie art. 69 ust. 1 Pr.przeds. oceny funkcjonowania tego aktu normatywnego lub jego części (art. 9 ust. 1 pkt 1 i 4 ustawy o RMSP).

14 Ocena skutków regulacji, druk nr 2052, Sejm VIII kadencji, s. 4.

15 Bliżej na temat instytucji objaśnień prawnych, o których mowa w art. 33 Pr.przeds., zob. A. Piszcz, Objaśnienia prawne wg ustawy z 6.3.2018 r. - Prawo przedsiębiorców, „Monitor Prawniczy” 2018, nr 13 (dodatek), s. 14 i n. 
Ad 4. Jeśli chodzi o podejmowanie działań na rzecz poprawy praktyki funkcjonowania organów, organizacji oraz instytucji publicznych w sprawach MSP, Rzecznik MSP ma obowiązek podejmować współpracę z organizacjami pozarządowymi, społecznymi i zawodowymi, do których celów statutowych należy ochrona praw przedsiębiorców, oraz współdziałać ze stowarzyszeniami, ruchami obywatelskimi, innymi dobrowolnymi zrzeszeniami i fundacjami oraz z zagranicznymi i międzynarodowymi organami i organizacjami na rzecz ochrony praw przedsiębiorców oraz poszanowania zasady wolności działalności gospodarczej i równego traktowania (art. 8 pkt 3 ustawy o RMSP). Może ponadto informować właściwe organy nadzoru lub kontroli o dostrzeżonych nieprawidłowościach w funkcjonowaniu organów administracji publicznej oraz informować o dostrzeżonych barierach i utrudnieniach w zakresie wykonywania działalności gospodarczej na terytorium Rzeczypospolitej Polskiej (art. 9 ust. 1 pkt 3 i 10 ustawy o RMSP). Rzecznik MSP może także zwracać się do właściwych organów, organizacji lub instytucji publicznych z ocenami i wnioskami o podjęcie działań zmierzających do zapewnienia skutecznej ochrony praw przedsiębiorców oraz usprawnienia trybu załatwiania spraw w tym zakresie (art. 11 ust. 1 ustawy o RMSP), te zaś sa zobowiązane współdziałać z Rzecznikiem MSP i udzielać mu pomocy. W szczególności muszą zapewnić dostęp do akt i dokumentów spraw zakończonych, udzielać żądanych informacji i wyjaśnień oraz udzielać wyjaśnień dotyczących podstawy faktycznej i prawnej swoich rozstrzygnięć (art. 12 ust. 1 i 2 ustawy o RMSP). Organy, organizacje lub instytucje publiczne sa zobowiąane ponadto do rozpatrzenia spraw skierowanych przez Rzecznika MSP i poinformowania go w terminie 30 dni o podjętych działaniach lub zajętym stanowisku. W przypadku nieotrzymania informacji lub gdy Rzecznik MSP nie podzieli ich stanowiska, może zwrócić się do właściwej jednostki nadrzędnej o podjęcie odpowiednich działań, a w przypadku gdy stwierdzi naruszenie praw przedsiębiorcy w działalności organów, organizacji lub instytucji publicznych, może zwrócić się z wnioskiem o wszczęcie postępowania wyjaśniającego lub dyscyplinarnego.

Ad 5. W zakresie ostatniego $\mathrm{z}$ wyróżnionych zadań, czyli propagowania wiedzy na temat prawa gospodarczego oraz przedsiębiorczości, rolą Rzecznika MSP jest inicjowanie i organizowanie działalności edukacyjnej i informacyjnej w zakresie związanym z wykonywaniem działalności gospodarczej na terytorium Rzeczypospolitej Polskiej, w szczególności w dziedzinie przedsiębiorczości oraz prawa gospodarczego (art. 8 pkt 4 ustawy o RMSP).

Jeśli chodzi o tryb działania Rzecznika MSP, to zgodnie z art. 10 ww. ustawy, podjęcie czynności przez Rzecznika MSP następuje z urzędu lub na wniosek, przy czym z wnioskiem moga zwracać się do tego organu nie tylko przedsiębiorcy, ale także organizacje przedsiębiorców. Po zapoznaniu się z wnioskiem Rzecznik MSP może podjąć czynności, wskazać wnioskodawcy przysługujące mu prawa i środki działania, przekazać sprawę według właściwości lub odmówić podjęcia czynności, zawiadamiając o tym wnioskodawcę i uzasadniając swoje stanowisko. W przypadku podjęcia czynności Rzecznik MSP ma obowiązek zbadać, czy wskutek działania lub zaniechania organu administracji publicznej nie nastapiło naruszenie praw lub interesów przedsiębiorcy. 


\section{POZYCJA PRAWNA RZECZNIKA MSP, CHARAKTER TEGO ORGANU ORAZ MIEJSCE WŚRÓD INNYCH RZECZNIKÓW PRAW}

Scharakteryzowane w poprzednim punkcie zadania i kompetencje Rzecznika MSP świadczą wyraźnie o tym, że organ ten należy do kategorii organów ochrony prawnej ${ }^{16}$. Rzecznik MSP jest przy tym co najmniej ósmym organem ochrony prawnej w Polsce, w którego nazwie występuje słowo „rzecznik”, po $\mathrm{RPO}^{17}$, Rzeczniku Praw Dziecka (RPD) ${ }^{18}$, Rzeczniku Finansowym ${ }^{19}$ (wcześniej Rzeczniku Ubezpieczonych), Powiatowym Rzeczniku Konsumentów ${ }^{20}$, Rzeczniku Praw Pacjenta ${ }^{21}$, Rzeczniku Praw Pacjenta Szpitala Psychiatrycznego (Rzecznik PPSP) ${ }^{22}$ oraz Rzeczniku Praw Pasażera Kolei (Rzecznik PPK) ${ }^{23}$, jeśli nie uwzględnimy rzeczników patentowych ${ }^{24}$, których rolą jest świadczenie określonych usług prawnych, nie zaś stanie na straży praw i wolności obywatelskich, oraz tych rzeczników praw, których funkcjonowanie nie jest wprost uregulowane w przepisach prawnych, tworzonych niejako „oddolnie” przez organizacje społeczne (jak Rzecznik Praw Obywateli Niepełnosprawnych ${ }^{25}$ )

${ }^{16}$ Zgodnie z utrwalonymi poglądami nauki prawa organy ochrony prawnej to „organy specjalnie powołane do sprawowania ochrony prawnej i specjalnie pod tym kątem zorganizowane”, które można podzielić na cztery zasadnicze grupy: 1) organy rozstrzygające (orzekajace), czyli przede wszystkim sądy, sądy polubowne oraz trybunały; 2) organy pojednawcze lub inaczej mediacyjne albo rozjemcze (jak np. utworzone ostatnio Centra Arbitrażu i Mediacji, działajacce przy Konfederacji Lewiatan); 3) organy kontroli legalności (jak np. Najwyższa Izba Kontroli, Inspekcja Handlowa, ale także organy policji, prokuratury, straże gminne, Straż Graniczna czy Centralne Biuro Antykorupcyjne) oraz 4) organy pomocy prawnej. Do tej ostatniej grupy zaliczane sa organy obsługi prawnej (jak adwokatura, radcostwo prawne czy notariat), organy obsługi legislacyjnej (np. Rządowe Centrum Legislacji), jak i organy określane mianem rzeczników praw, stojące na straży szeroko pojętych praw i wolności obywatelskich. Zob. S. Włodyka, Ustrój organów ochrony prawnej, Warszawa 1975, s. 24 i n. Do podziału zaproponowanego przez Włodykę nawiązuja autorzy najnowszych opracowań poświęconych organom ochrony prawnej; zob. w szczególności S. Serafin, B. Szmulik, Organy ochrony prawnej RP, Warszawa 2010, s. 6 i n.; J. Bodio, Klasyfikacja organów ochrony prawnej, w: idem, G. Borkowski, T. Demendencki, Ustrój organów ochrony prawnej. Część szczegótowa, Warszawa 2013, s. 23 i n.

${ }_{17}$ Ustawa z 15 lipca 1987 r. o Rzeczniku Praw Obywatelskich, t.jedn.: Dz. U. 2017, poz. 958 ze zm. (dalej jako: ustawa o RPO).

${ }_{18}$ Ustawa z 6 stycznia 2000 r. o Rzeczniku Praw Dziecka, t.jedn.: Dz. U. 2017, poz. 922 (dalej jako: ustawa o RPD).

${ }^{19}$ Ustawa z 5 sierpnia 2015 r. o rozpatrywaniu reklamacji przez podmioty rynku finansowego i o Rzeczniku Finansowym, t.jedn.: Dz. U. 2017, poz. 2270 ze zm. (dalej jako: ustawa o PRFiRF).

${ }^{20}$ Ustawa z 16 lutego 2007 r. o ochronie konkurencji i konsumentów, t.jedn.: Dz. U. 2018, poz. $798 \mathrm{ze} \mathrm{zm}$.

${ }^{21}$ Ustawa z 6 listopada 2008 r. o prawach pacjenta i Rzeczniku Praw Pacjenta, t.jedn.: Dz. U. 2017, poz. 1318 ze zm.

${ }^{22}$ Ustawa z 19 sierpnia 1994 r. o ochronie zdrowia psychicznego, t.jedn.: Dz. U. 2017, poz. 882 ze zm.

${ }^{23}$ Ustawa z 28 marca 2003 r. o transporcie kolejowym, t.jedn.: Dz. U. 2017, poz. 2117 ze zm.

${ }^{24}$ Ustawa z 11 kwietnia 2001 r. o rzecznikach patentowych, t.jedn.: Dz. U. 2017, poz. 1314 ze $\mathrm{zm}$.

${ }^{25} \mathrm{Na}$ temat tej instytucji zob. <http://idn.org.pl/sonnszz/UPRAWNIENIA.htm> [dostęp: $5.09 .2018]$. 
lub przez organy i instytucje publiczne (jak Rzecznik Praw Ucznia działajacy w instytucjach oświatowych, czy Rzecznik Odbiorców Paliw i Energii działający swego czasu przy Prezesie Urzędu Regulacji Energetyki).

Pozycja prawna poszczególnych rzeczników praw jest bardzo zróżnicowana. Punktem odniesienia oceny pozycji prawnej Rzecznika MSP, jak również pozostałych ww. organów, powinna być szwedzka instytucja ombudsmana, do której porównywani sa rzecznicy praw, działajacy zwłaszcza w krajach europejskich, a także m.in. w Kanadzie, Australii czy Nowej Zelandii ${ }^{26}$, łącznie w ponad 110 krajach na całym świecie ${ }^{27}$. Zgodnie z art. 43 Karty praw podstawowych $^{28}$ na szczeblu unijnym działa Europejski Rzecznik Praw Obywatelskich. Powodem tych odniesień jest wyjątkowo długa tradycja szwedzkiej instytucji, która sięga początku XVIII w., i jej szczególne cechy, powielane przy kształtowaniu instytucji rzeczników w ww. ustawodawstwach.

Do „klasycznych” cech ombudsmana zalicza się przede wszystkim sprawowanie ochrony praw i wolności obywateli oraz innych podmiotów przed naruszeniami ze strony państwa i jego organów, powoływanie przez parlament, a tylko w nielicznych państwach przez głowę państwa (co gwarantować ma niezależność od władzy wykonawczej, a także sądowniczej), łatwy dostęp do tego organu dla skarżących (a w związku z tym bezpłatność udzielanej ochrony prawnej), działanie w odformalizowanym i szybkim postępowaniu, a także to, że zadaniem ombudsmana nie jest rozstrzyganie spraw czy nakładanie sankcji ${ }^{29}$. Przedstawione cechy nie wykluczaja przyjmowania w poszczególnych państwach różnych modeli organizacyjnych instytucji ombudsmana ${ }^{30}$. Choć za dominujące rozwiązanie należy uznać centralne usytuowanie tej instytucji i przypisanie jej kompetencji ogólnych, to znane sa przypadki powoływania ombudsmanów wyspecjalizowanych w określonych kategoriach spraw (np. w sprawach wojskowych, w sprawach dzieci, czy w sprawach mniejszości narodowych i etnicznych ${ }^{31}$ ), czy ombudsmanów lokalnych (np. właściwych dla regionów autonomicznych lub krajów wchodzących w skład państwa federalnego $)^{32}$.

Od instytucji ombudsmana wyraźnie oddzielani są quasi-ombudsmani, co oznacza organy noszące często nazwę rzecznika, lecz powoływane nie przez parlament, lecz przez organy władzy wykonawczej, względnie przez rozmaite organizacje i stowarzyszenia, i przed nimi odpowiedzialne. Mają one za zada-

${ }^{26}$ G. Borkowski, Rzecznicy praw i wolności, w: J. Bodio, G. Borkowski, T. Demendencki, op. cit., s. 452 i n.

27 Zob. J. Uliasz, Rzecznik Praw Obywatelskich, w: H. Zięba-Załucka (red.), Organy państwowe w ustroju konstytucyjnym RP, Rzeszów 2016, s. 415.

${ }^{28}$ Karta praw podstawowych Unii Europejskiej z 14 grudnia 2007 r., Dz. Urz. UE z 7 czerwca 2016 r., C 202/02.

${ }_{29}$ Tak m.in. L. Garlicki, Ewolucja instytucji rzecznika praw obywatelskich (ombudsmana) w świecie wspótczesnym, w: idem (red.), Rzecznik Praw Obywatelskich, Warszawa 1989, s. 15; I. Malinowska, Rzecznik Praw Obywatelskich w systemie ochrony praw i wolności w Polsce, Warszawa 2007, s. 57; J. Świątkiewicz, Rzecznik Praw Obywatelskich, Warszawa 2001, s. 16.

${ }^{30}$ Tak A. Deryng, Rzecznik Praw Obywatelskich jako wnioskodawca $w$ postepowaniu przed Trybunatem Konstytucyjnym, Warszawa 2014, s. 45.

31 Bliżej na ten temat zob. I. Malinowska, op. cit., s. 64.

32 Ibidem, s. 65 i n. 
nie strzeżenie praw i wolności obywatelskich, lecz brakuje im cechy niezależności od władzy wykonawczej czy od organizacji, które je powołały.

W polskim systemie prawnym ombudsmanem - w pełnym tego słowa znaczeniu - jest bez wątpienia RPO, którego pozycję prawną określają wprost przepisy Konstytucji RP ${ }^{33}$. Stoi on na straży wolności i praw człowieka i obywatela określonych zarówno w przepisach KRP, jak i w innych aktach normatywnych (art. 208 ust. 1 KRP). Jak zauważa Irena Lipowicz, organ ten stoi nie tylko na straży prawa, ale także na straży sprawiedliwości społecznej, zwłaszcza poprzez monitorowanie sposobu osiagania celów społecznych i konstytucyjnych standardów regulacji oraz proporcji alokacji środków publicznych $^{34}$. O wysokiej, niezależnej pozycji względem innych organów państwa, a zwłaszcza względem organów władzy wykonawczej, przesądza sposób powoływania RPO. Zgodnie z art. 209 ust. 1 KRP powoływany jest przez Sejm za zgodą Senatu na 5 lat. Zgodnie zaś z przepisami ustawy o RPO (art. 5 ust. 2), sprawowanie funkcji RPO przez tę samą osobę dopuszczalne jest przez dwie kolejne kadencje. Konstytucja określa w odniesieniu do tej osoby zasadę niepołączalności jej funkcji z innym stanowiskiem, poza stanowiskiem profesora szkoły wyższej, zakaz wykonywania innych zajęć zawodowych, a także zakaz przynależności do partii politycznych oraz związków zawodowych. Ponadto organ ten posiada konstytucyjnie zagwarantowany immunitet (art. $211 \mathrm{KRP}$ ).

Za ombudsmana o wyspecjalizowanych kompetencjach należy uznać RPD. Także o tym organie mowa jest w przepisach KRP. Co prawda przepisów tych jest niewiele i nie zostały umieszczone w rozdziale IX KRP, dotyczacym organów kontroli państwowej i ochrony prawa, jednakże sam fakt zawarcia w KRP przepisów mówiących o RPD wskazuje na wysoką rangę tego rzecznika praw, ustępująca jedynie randze RPO. Chodzi tu o art. 72 ust. $1 \mathrm{KRP}$, zgodnie z którym Rzeczpospolita Polska zapewnia ochronę praw dziecka, oraz ust. 4 tego artykułu, który stwierdza, iż ustawa określa kompetencje i sposób powoływania RPD. Istnienie jedynie tak lakonicznych przepisów odnoszących się do RPD wyjaśniane jest faktem, że zostały one wprowadzone to tekstu KRP w ostatniej fazie prac Komisji Konstytucyjnej ${ }^{35}$. Jeśli chodzi o zakres praw chronionych przez RPD, zgodnie z art. 1 ust. 2 ustawy o RPD, organ ten stoi na straży praw dziecka określonych w KRP, Konwencji o prawach dziecka i innych przepisach prawa, z poszanowaniem odpowiedzialności, praw i obowiązków rodziców. Organ ten powoływany jest - analogicznie do RPO - przez Sejm za zgodą Senatu na 5-letnią kadencję i także w tym przypadku dopuszczalne jest sprawowanie funkcji rzecznika przez tę samą osobę przez dwie kolejne kadencje (art. 4 ust. 1 oraz art. 6 ust. 3 ustawy o RPD). Ponadto organ ten posiada ustawowo zagwarantowany immunitet.

${ }^{33}$ Konstytucja Rzeczypospolitej Polskiej z 2 kwietnia 1997 r., Dz. U. 1997, Nr 78, poz. 483 ze zm. (dalej jako: KRP).

34 Zob. I. Lipowicz, Stan ochrony praw człowieka z perspektywy Rzecznika Praw Obywatelskich, RPEiS 74, 2014, z. 2, s. 139.

35 Zob. A. Zieliński, Rzecznik Praw Obywatelskich - przeszłość, teraźniejszość, przyszłość, w: Obywatel - jego wolności i prawa. Zbiór studiów przygotowanych z okazji 10-lecia urzędu Rzecznika Praw Obywatelskich, Warszawa 1998, s. 20. 
Przechodząc do regulacji prawnych odnoszących się ściśle do Rzecznika MSP, w pierwszej kolejności należy zauważyć, że zasady powoływania tego organu różnią się od zasad powoływania RPO i RPD. Już ta okoliczność wywołuje wątpliwość, czy możemy mówić tu o instytucji ombudsmana czy raczej o innego typu instytucji będącej quasi-ombudsmanem, zgodnie z przytoczona wyżej typologią organów ochrony prawnej noszących miano „rzecznika”. Zgodnie z art. 3 ust. 1 i 2 ustawy o RMSP - Rzecznika MSP nie powołuje Sejm, lecz Prezes Rady Ministrów (Prezes RM) na wniosek ministra właściwego do spraw gospodarki, a przed złożeniem tego wniosku minister zasięga opinii reprezentatywnych organizacji pracodawców w rozumieniu ustawy o $\mathrm{RDS}^{36}$. Różnica jest także brak immunitetu Rzecznika MSP. Ustawa o RMSP w art. 2 określa szczegółowe wymogi wobec osoby powoływanej na stanowisko Rzecznika MSP, w tym specyficzny dla pełnienia tej funkcji wymóg wyróżniania się „wiedzą w zakresie przedsiębiorczości i regulacji prawnych tworzących otoczenie przedsiębiorców” oraz posiadaniem „co najmniej pięcioletniego doświadczenia w zakresie wykonywania działalności gospodarczej lub reprezentowania interesów przedsiębiorców, lub tworzenia lub stosowania prawa gospodarczego". Kadencja Rzecznika MSP trwa 6 lat (jest więc dłuższa niż 5-letnia kadencja RPO i RPD), a sprawowanie funkcji Rzecznika MSP przez tę samą osobę dopuszczalne jest tylko przez jedna kadencje (art. 4 ust. 1 i 2). Ustawa przewiduje możliwość odwołania tego organu przez Prezesa RM przed upływem kadencji (wymagany jest w takim przypadku wniosek ministra właściwego do spraw gospodarki) w przypadkach ściśle, choć dość szeroko określonych w art. 5 ustawy o RMSP ${ }^{37}$. Artykuł 6 ust. 1 wymienionej ustawy wyraża zasadę niepołączalności tej funkcji z innym stanowiskiem z wyjątkiem stanowiska naukowo-dydaktycznego lub naukowego w szkole wyższej, Polskiej Akademii Nauk, instytucie badawczym lub innej jednostce naukowej oraz zakaz wykonywania innych zajęć zawodowych. Osobie powołanej na stanowisko Rzecznika MSP przepisy ustawy o RMSP zabraniaja ponadto przynależności do partii politycznej, wykonywania innych czynności, które pozostają w sprzeczności z jej obowiązkami albo moga wywołać podejrzenie o stronniczość lub interesowność, jak również prowadzenia działalności publicznej niedającej się pogodzić z obowiązkami i godnością jego urzędu. Rzecznik MSP może wykonywać swoje zadania przy pomocy jednego zastępcy, którego - na wniosek Rzecznika

${ }^{36}$ Ustawa z 24 lipca 2015 r. o Radzie Dialogu Społecznego i innych instytucjach dialogu społecznego, Dz. U. 2015, poz. 1240 ze zm.

${ }^{37}$ Są to następujace przypadki: złożenie rezygnacji, utrata obywatelstwa polskiego, trwała niezdolność do pełnienia obowiązków ze względu na stan zdrowia - stwierdzona orzeczeniem lekarskim, prawomocne skazanie za umyślne przestępstwo lub umyślne przestępstwo skarbowe, rażące naruszenie przepisów ustaw w związku z pełnieniem funkcji, ustalenie niespełniania lub zaprzestania spełniania trzech (z siedmiu) warunków wymaganych przy powoływaniu na stanowisko Rzecznika MSP, a mianowicie: korzystania z pełni praw publicznych, posiadania wyższego wykształcenia oraz niepełnienia służby zawodowej ani bycia zatrudnionym w organach bezpieczeństwa państwa wymienionych w art. 2 ustawy z 18 października 2006 r. o ujawnianiu informacji o dokumentach organów bezpieczeństwa państwa z lat 1944-1990 oraz treści tych dokumentów (Dz. U. 2017, poz. 2186 ze zm.), ani bycia współpracownikiem tych służb. 
MSP - powołuje minister właściwy do spraw gospodarki ${ }^{38}$. Może natomiast samodzielnie ustanawiać pełnomocników terenowych spośród pracowników swego Biura (art. 7 ust. 1-3 ustawy o RMSP).

Powoływanie Rzecznika MSP przez Prezesa Rady Ministrów, czyli w sposób charakterystyczny dla powoływania wielu centralnych organów administracji, nasuwa pytanie, czy organ ten należy przypisać ściśle do kategorii organów administracji publicznej (w tym przypadku administracji rządowej). W moim przekonaniu mamy tu do czynienia ze swoista hybryda - instytucja, która nie spełnia wymogów niezbędnych do uznania jej za „klasyczny” typ ombudsmana (gdyż nie jest powoływana przez parlament lub głowę państwa), a która - obok cech organu administracji (sposób powoływania, podobne do innych organów administracji zadania w zakresie „wspierania działalności gospodarczej”) - posiada także pewne cechy „klasycznego ombudsmana, jeśli chodzi o charakter zadań, bardzo dużą niezależność od rządu (w szczególności od Prezesa RM), a przy tym bardzo wysoka pozycję na tle innych rzeczników praw. W rezultacie trudno dokonać jej jednoznacznej kwalifikacji jako organu administracji rządowej, a w konsekwencji jako quasi-ombudsmana. Instytucji tej bliżej jest raczej do „ombudsmana o wyspecjalizowanych kompetencjach”. Przekonanie to opieram na następujących szczegółowych argumentach.

Po pierwsze, przemawiają za tym przesłanki formalnoprawne. Otóż we wspomnianym już projekcie ustawy o KWRiPoRP zawarty był przepis (art. 23 ust. 1) stanowiący wprost, iż: „Rzecznik jest centralnym organem administracji rządowej”. Tymczasem w ustawie o RMSP, której zdecydowana większość przepisów stanowi niemal dosłowne powtórzenie przepisów wymienionego projektu, cytowanego przepisu już nie umieszczono. W moim przekonaniu świadczy to wyraźnie o zmianie koncepcji co do pozycji Rzecznika MSP w porównaniu z pozycją Rzecznika Przedsiębiorców.

Po drugie, szczególnych zadań Rzecznika MSP, polegających na przeciwdziałaniu ingerencji organów władzy publicznej, w tym organów administracji, w konstytucyjnie zagwarantowaną wolność działalności gospodarczej nie można uznać za wykonywanie zadań administracji publicznej ani przyporządkować do żadnej z wyróżnianych przez naukę prawa funkcji tej administra$\mathrm{cji}^{39}$. Oczywiste jest także to, że realizowanie tego typu zadań musi odbywać się z pozycji niezależnej od administracji. Przynależność Rzecznika MSP do

${ }^{38}$ Kandydat na stanowisko zastępcy Rzecznika MSP musi spełniać takie same wymagania, jak wymagania stawiane kandydatowi na stanowisko Rzecznika MSP. Ustawa o RMSP nie określa jednak kadencji tego organu. Do jego odwołania uprawiony jest minister właściwy do spraw gospodarki i dokonuje tego albo z powodów określonych w art. 5 wymienionej ustawy, albo na wniosek Rzecznika MSP. Co ciekawe, odnoszące się do Rzecznika MSP wymogi w zakresie niepołączalności tej funkcji z innym stanowiskiem, a także zakaz przynależności do partii politycznej oraz wykonywania innych wymienionych w ustawie o RMSP czynności stosuje się do zastępcy Rzecznika MSP - zgodnie z art. 7 ust. 3 tej ustawy - jedynie „odpowiednio”, a zatem nie wprost.

${ }^{39} \mathrm{Na}$ temat wyróżnianych przez naukę prawa funkcji administracji zob. w szczególności: I. Lipowicz, Istota administracji, w: Z. Niewiadomski (red.), Prawo administracyjne, Warszawa 2013, s. 27-28; jeśli chodzi o funkcje administracji w sferze gospodarczej, zob. B. Popowska, Klasyfikacja funkcji administracji w nauce publicznego prawa gospodarczego, w: eadem (red.), Funkcje wspótczesnej administracji gospodarczej. Księga dedykowana Profesor Teresie Rabskiej, Poznań 2006 , s. 61 i n. 
administracji publicznej musiałaby bowiem wzbudzać watpliwość co do jego bezstronności i podważać zaufanie przedsiębiorców do jego działań. Dotyczy to zwłaszcza sytuacji konfliktowych, kiedy w różnego rodzaju sporach przedsiębiorców z organami administracji Rzecznik MSP, niejako z samej definicji, powinien bronić słusznego interesu przedsiębiorców.

Warte podkreślenia jest zatem to, że Rzecznik MSP posiada niespotykaną w odniesieniu do innych organów administracji niezależność. Oparta jest ona nie tylko na powoływaniu na 6-letnią kadencję i prawnych gwarancjach nieodwoływalności w trakcie kadencji. Należy zauważyć, że organ ten, inaczej niż w przypadku „wyspecjalizowanych organów administracji niezależnych od rządu"40, także powoływanych na określoną (najczęściej 5-letnia) kadencję, jak np. Prezes Urzędu Regulacji Energetyki, Prezes Urzędu Komunikacji Elektronicznej czy Prezes Urzędu Lotnictwa Cywilnego, nie podlega tym uprawnieniom nadzorczym ze strony organów rządowych, które wiążą się z koordynowaniem jego działań z polityką rządu. Tymczasem wymienione „wyspecjalizowane organy”, choć zachowują niezależność w wymiarze merytorycznym dotyczącym ścisłej sfery ich zadań i kompetencji, to podlegaja jednak określonym uprawnieniom nadzorczym (czy to ze strony Prezesa RM, czy to ze strony określonych ministrów ${ }^{41}$ ), związanym z koordynowaniem polityki rządu w sferze gospodarczej i mającym na celu zachowanie jej spójności, współdziałają ponadto w jej realizowaniu (zwłaszcza w obszarze polityk sektorowych), dokonują wymiany informacji, uczestniczą w rozmaitych konsultacjach czy pracach zespołów międzyresortowych ${ }^{42}$. Ustawa o RMSP nakłada zaś na Rzecznika MSP jedynie obowiąek corocznego przedstawiania Prezesowi RM, w terminie 90 dni od zakończenia roku kalendarzowego, a także podawania do publicznej wiadomości sprawozdania z działalności w poprzednim roku kalendarzowym. Sprawozdanie to zawiera w szczególności informacje o podjętych przez Rzecznika MSP w danym roku czynnościach, a także uwagi o stanie przestrzegania praw przedsiębiorców oraz dostrzeżonych barierach i utrudnieniach w zakresie wykonywania działalności gospodarczej na terytorium Rzeczypospolitej Polskiej (art. 14).

Trzeci argument przemawiający za tym, że Rzecznik MSP posiada szczególną pozycję w systemie organów państwa, oparty jest na treści przepisów ustawy o RPO, które nakładają na Rzecznika Praw Obywatelskich obowiązek współpracy z Rzecznikiem Praw Dziecka (w sprawach dzieci) oraz z Rzecznikiem MSP

${ }^{40}$ Bliżej na temat tej kategorii organów zob. P. Lissoń, Funkcje administracji gospodarczej a wyspecjalizowane organy administracji (ze szczególnym uwzględnieniem organów niezależnych od rzadu), w: B. Popowska (red.), op. cit., s. 106 i n.

${ }^{41}$ Zgodnie z art. 33a ust. 1 pkt 15 ustawy z 4 września 1997 r. o działach administracji rządowej (t.jedn.: Dz. U. 2018, poz. 798 ze zm.), Prezes Rady Ministrów sprawuje nadzór nad działalnością Urzędu Regulacji Energetyki. Zgodnie z art. 12a ust. 2 tej ustawy minister właściwy do spraw informatyzacji sprawuje nadzór nad Prezesem Urzędu Komunikacji Elektronicznej. Art. 27 ust. 2 wymienionej ustawy stanowi z kolei, iż minister właściwy do spraw transportu sprawuje nadzór nad Prezesem Urzędu Lotnictwa Cywilnego.

${ }^{42} \mathrm{Na}$ ten temat w odniesieniu do nadzoru Prezesa RM nad działalnością Prezesa Urzędu Regulacji Energetyki zob. M. Swora, Organ do spraw regulacji gospodarki paliwami $i$ energia, w: idem, Z. Muras (red.), Prawo energetyczne, t. 2: Komentarz do art. 12-72, wyd. 2, Warszawa 2016, s. $180-181$. 
(w sprawach MSP). Stanowia o tym art. 2a oraz (dodany w zwiazku z uchwaleniem Konstytucji Biznesu) art. 2b ustawy o RPO, kształtując w ten sposób swoistą rzecznikowska „trojkę” (nawiązując do nazwy zaprzęgu, w którego skład wchodzą trzy konie, jeden po środku i dwa zaprzężone po bokach), obejmująca RPO jako organ o kompetencjach najszerszych (ogólnych) i dwóch wyspecjalizowanych rzeczników w postaci RPD i Rzecznika MSP. W moim przekonaniu tym sposobem ustawodawca w jakimś sensie „zrównuje” Rzecznika MSP (quasi-ombudsmana) z RPD (ombudsmanem wyspecjalizowanym), co wyklucza traktowanie Rzecznika MSP wyłacznie w kategoriach organu administracji, wszystkie trzy wymienione organy pozwala zaś uznać za najważniejszych rzeczników praw, a dziedziny ich zadań i kompetencji za trzy najważniejsze obszary ochrony praw i wolności (notabene nie takie były pierwotne założenia Konstytucji Biznesu, które nie przewidywały zmian w przepisach ustawy o RPO i tym samym udziału we wskazanej wyżej „trojce” Rzecznika Przedsiębiorców ${ }^{43}$ ). Z przepisami nakładającymi na RPO obowiązek współpracy z RPD i Rzecznikiem MSP koresponduje treść art. 9 ustawy o RPO, zgodnie z którym podjęcie czynności przez RPO następuje m.in. na wniosek Rzecznika MSP lub RPD.

Nawiasem mówiąc, choć koncepcja wyrażona w przepisach ustawy o RPO stanowi potwierdzenie (co oczywiste) naczelnej rangi RPO jako najważniejszego ze wszystkich rzeczników praw, to ustanowienie „wyspecjalizowanych rzeczników”, z którymi RPO ma obowiązek współdziałać, zdaje się przeczyć formułowanej w literaturze prawnej „koncepcji rzecznikowskiej”. Koncepcja ta, prezentowana w szczególności przez Adama Zielińskiego ${ }^{44}$, wychodzi z założenia, że z punktu widzenia skutecznej ochrony praw i wolności obywatelskich największe gwarancje daje urząd odpowiednio silny. Wynika z niej postulat utrzymania głównej roli RPO w zakresie ochrony praw i wolności obywateli, przy jednoczesnym ograniczaniu tendencji do powoływania odrębnych, „wyspecjalizowanych rzeczników”, i nienaruszania tej koncepcji przy okazji opracowywania różnych szczegółowych ustaw. Autor ten zauważa bowiem, że choć istnieją kraje, w których - podobnie jak w Polsce - istnieje kilku ombudsmanów specjalizujących się w różnych dziedzinach, to jednak intensywność ochrony praw i wolności wcale na tym nie zyskuje.

$\mathrm{Na}$ koniec prezentowanych w tej części ustaleń wypada zauważyć, że podobne do Rzecznika MSP zasady powoływania i odwoływania dotyczą Rzecznika Finansowego. Organ ten powoływany jest przez Prezesa RM na wniosek ministra właściwego do spraw instytucji finansowych na 4-letnią kadencję (dopuszczalne jest sprawowanie funkcji rzecznika przez tę samą osobę przez dwie kolejne kadencje), w trakcie której może zostać odwołany jedynie w przypadku zaistnienia ściśle określonych w ustawie okoliczności ${ }^{45}$. W odniesieniu do tego organu znacznie trudniej jednak sformułować tezę, że jest to organ o zadaniach odbiegajaccych od sprawowania administracji publicznej. Funkcją tego

${ }^{43}$ Wynika to z analizy przepisów projektu ustawy Przepisy wprowadzające ustawę - Prawo przedsiębiorców oraz niektóre inne ustawy z pakietu „Konstytucji Biznesu”, <https://legislacja.rcl. gov.pl/projekt/12295755> [dostęp: 5.09.2018].

${ }_{44}$ Zob. A. Zieliński, op. cit., s. 22 i n.

${ }^{45}$ Art. 11-15 ustawy o PRFiRF. 
organu nie jest bowiem przeciwdziałanie nadmiernej ingerencji organów władzy publicznej w konstytucyjnie zagwarantowaną wolność działalności gospodarczej (jak w przypadku Rzecznika MSP), lecz ochrona interesów klientów podmiotów rynku finansowego, w tym - charakterystyczna dla organów administracji - możliwość rozstrzygania i nakładania sankcji w postaci administracyjnych kar pieniężnych. Słusznie zatem komentatorzy ustawy o PRFiRF są zdania, że w tym przypadku mamy do czynienia z organem kwalifikowanym definitywnie administracji publicznej ${ }^{46}$. Ponadto sam ustawodawca obniżył rangę tego rzecznika, uchylając przepisy mówiące o współpracy tego organu z Rzecznikiem Praw Obywatelskich ${ }^{47}$. Niższą od Rzecznika MSP pozycję posiada także Rzecznik PPK, co wynika z różnicy pomiędzy charakterem realizowanych przez ten organ zadań a charakterem zadań Rzecznika MSP (analogicznej do ukazanej w odniesieniu do zadań Rzecznika Finansowego). Rzecznik PPK na 5-letnia, jednokrotną kadencję powoływany jest nie przez Prezesa RM, lecz przez centralny organ administracji rządowej, jakim jest Prezes Urzędu Transportu Kolejowego. Za nieporównywalną z pozycją Rzecznika MSP należy uznać także pozycję Rzecznika Praw Pacjenta. Po pierwsze, nie jest to organ kadencyjny; po drugie, o tym, że jest to centralny organ administracji rządowej, stanowią wprost właściwe przepisy prawne; po trzecie zaś, Prezes RM, który powołuje Rzecznika Praw Pacjenta, posiada wyraźnie określone kompetencje nadzorcze nad działalnością tego organu ${ }^{48}$. Jeszcze niższą rangę posiadają Rzecznicy PPSP, którzy posiadają status pracowników biura Rzecznika Praw Pacjenta ${ }^{49}$, oraz Powiatowi Rzecznicy Konsumentów, którzy posiadają status pracowników samorządowych (zatrudnianych przez starostów powiatów) $)^{50}$.

\section{WNIOSKI}

Jak wynika z przedstawionych ustaleń, nie jest możliwa jednoznaczna odpowiedź na pytanie zawarte w tytule artykułu. Z jednej strony Rzecznik MSP nie posiada tej istotnej cechy ombudsmana, jaka jest powoływanie przez parlament lub przez głowę państwa. Z drugiej strony, choć powoływany jest przez Prezesa RM (i przez ten organ odwoływany, jeśli zajdą szczególne oko-

${ }_{46}$ Tak M. Chołodecki, M. Strzelbicki, Ustawa o rozpatrywaniu reklamacji przez podmioty rynku finansowego i o Rzeczniku Finansowym. Komentarz, Warszawa 2017, s. 51.

${ }_{47}$ Chodzi o uchylony z dniem 11 października 2015 r. art. 5 ustawy z 22 maja 2003 r. o nadzorze ubezpieczeniowym i emerytalnym (t.jedn.: Dz. U. 2016, poz. 477 ze zm.).

48 Art. 42 ust. 1 i 2 ustawy o prawach pacjenta i Rzeczniku Praw Pacjenta. Jeśli chodzi o relacje pomiędzy Rzecznikiem Praw Pacjenta a innymi rzecznikami, zgodnie z art. 48 wymienionej ustawy, organ ten może zwrócić się do RPO lub RPD o podjęcie działań z zakresu ich kompetencji.

${ }^{49} \mathrm{O}$ czym stanowi art. 10d ustawy o ochronie zdrowia psychicznego, a także art. 56 ustawy o prawach pacjenta i Rzeczniku Praw Pacjenta. Jeśli chodzi o relacje pomiędzy Rzecznikiem PPSP a innymi rzecznikami, zgodnie z art. 10b ust. 3 wymienionej ustawy, w zakresie wykonywania swych zadań Rzecznik PPSP współpracuje m.in. z RPO oraz RPD.

${ }^{50} \mathrm{O}$ czym stanowi art. 40 ust. 1 ustawy o ochronie konkurencji i konsumentów. 
liczności określone w ustawie o RMPSP), to charakter jego zadań i kompetencji, nakierowanych na przeciwdziałanie ingerencji ze strony organów władzy publicznej, w tym zwłaszcza organów administracji, w konstytucyjnie zagwarantowana wolność działalności gospodarczej oraz w dużym stopniu niezależna od władzy wykonawczej pozycja prawna pozwalają uznać, że mamy do czynienia z organem o złożonym, hybrydowym charakterze - łączącym cechy ombudsmana (o wyspecjalizowanych kompetencjach) i zarazem organu administracji rządowej.

Rzecznik MSP jest organem o szerokim i zróżnicowanym zakresie zadań. W artykule została podjęta próba usystematyzowania tych zadań przez wyodrębnienie ich najważniejszych kategorii. Jak ustalono, w zakresie zadań polegających na podejmowaniu interwencji w indywidualnych sprawach MSP oraz działań na rzecz jednolitej wykładni przepisów prawnych dotyczących działalności gospodarczej, obecnie jedynym właściwym organem jest Rzecznik MSP. W zakresie tych zadań, które można określić ogólnym mianem „wspierania działalności gospodarczej” właściwe są także inne organy i instytucje, co podkreśla wyjątkową rangę zadań należących do pierwszej z wyróżnionych grup i szczególną rolę Rzecznika MSP. Które z zadań Rzecznika MSP realizowane będą z największą intensywnościa, pokaże praktyka działania tego organu ${ }^{51}$, bądź co bądź dobrze wyposażonego w środki finansowe. Roczny budżet Rzecznika MSP ${ }^{52}$ stanowi ponad $40 \%$ budżetu RPO, czyli ombudsmana o właściwości ogólnej, który posiada najszersze kompetencje w zakresie udzielania ochrony prawnej, w tym również dla mikro-, małych i średnich przedsiębiorców.

dr Piotr Lissoń

Uniwersytet im. Adama Mickiewicza w Poznaniu

piotr.lisson@amu.edu.pl

https://orcid.org/0000-0003-4568-3637

\section{OMBUDSMAN FOR SMALL AND MEDIUM-SIZED ENTERPRISES: OMBUDSMAN OR A GOVERNMENT ADMINISTRATION BODY?}

Summary

The Ombudsman for Small and Medium-sized Enterprises (SME Ombudsman) is a new state body established pursuant to the Act of 6 March 2018. The author analyses its nature, asking whether it is another specialised body of government administration or maybe a special kind of ombudsman, that is to say an Ombudsman specialised in the protection of the rights of micro-, small and medium-sized enterprises (SMEs). First of all, the tasks and competences of the SME Ombudsman are analysed and a suggestion how to systematise them presented. The analysis leads to the conclusion that within the scope of intervention in individual cases

${ }^{51}$ Realizując postanowienia art. 210 ustawy - Przepisy wprowadzające, Prezes RM 22 czerwca 2018 r. powołał na stanowisko Rzecznika MSP Adama Abramowicza i utworzył Biuro Rzecznika MSP; zob. bliżej <https://konstytucjabiznesu.biz/rzecznik-malych-i-srednich-przedsiebiorcow-siedziba/> [dostęp: 5.09.2018].

${ }^{52} \mathrm{~W}$ corocznej wysokości $18 \mathrm{mln}$ zł (art. 17 ustawy o RMSP) w porównaniu z 42 mln 639 tys. zł budżetu RPO w 2018 r.; dane ze strony internetowej RPO [dostęp: 5.09.2018]. 
of SMEs and activities aimed at a uniform interpretation of economic law, the only competent body to act seems to be the SME Ombudsman and the fact these tasks have not been regulated by the economic law provisions, emphasises the exceptional nature of these tasks and the special role of the SME Ombudsman. An analysis of the tasks and competences of the SME Ombudsman, the rules on the appointment and dismissal of that body, as well as comparative analyses relating to the original legislative approach to the institution and the status of other bodies referred to as ombudsmen suggest it is a high-profile body of legal protection. The author comes to the conclusion that it is of a hybrid nature, which cannot be strictly placed either within the category of a fully independent ombudsman, not dependent of the executive power, or within the category of a typical public administration body. 
